\title{
Mechanism of mitochondrial stress-induced resistance to apoptosis in mitochondrial DNA-depleted C2C12 myocytes
}

\author{
G Biswas ${ }^{1}$, HK Anandatheerthavarada ${ }^{1}$ and NG Avadhani ${ }^{\star, 1}$ \\ 1 Department of Animal Biology and the Mari Lowe Center for Comparative \\ Oncology, School of Veterinary Medicine, University of Pennsylvania, \\ Philadelphia, PA 19104, USA \\ * Corresponding author: NG Avadhani, Department of Animal Biology and the \\ Mari Lowe Center for Comparative Oncology, School of Veterinary Medicine, \\ University of Pennsylvania, Philadelphia, PA 19104, USA. Fax: 2155736651; \\ E-mail: narayan@vet.upenn.edu
}

Received 22.9.04; accepted 10.11.04; published online 14.1.05 Edited by DR Green

\begin{abstract}
In this study, we show that partial mitochondrial DNA (mtDNA) depletion (mitochondrial stress) induces resistance to staurosporine (STP)-mediated apoptosis in $\mathrm{C} 2 \mathrm{C} 12$ myoblasts. MtDNA-depleted cells show a 3-4-fold increased proapoptotic proteins (Bax, BAD and Bid), markedly increased antiapoptotic $\mathrm{BCl}-2$, and reduced processing of p21 Bid to active tBid. The protein levels and also the ability to undergo STPmediated apoptosis were restored in reverted cells containing near-normal mtDNA levels and restored mitochondrial transmembrane potential. Inhibition of apoptosis closely correlated with sequestration of Bax, Bid and BAD in the mitochondrial inner membrane, increased $\mathrm{Bcl}-2$ and $\mathrm{Bcl}-\mathrm{X}_{\mathrm{L}}$, and inability to process p21 Bid. These factors, together with the reduced activation of caspases 3,9 and 8 are possible causes of mitochondrial stress-induced resistance to apoptosis. Our results suggest that a highly proliferative and invasive behavior of mtDNA-depleted C2C12 cells is related to their resistance to apoptosis.

Cell Death and Differentiation (2005) 12, 266-278.

doi:10.1038/sj.cdd. 4401553

Published online 14 January 2005
\end{abstract}

Keywords: mitochondrial DNA; membrane potential; apoptosis; mitochondrial stress; $\mathrm{Bcl}-2$ family proteins

\begin{abstract}
Abbreviations: mtDNA, mitochondrial DNA; $\Delta \Psi_{\mathrm{m}}$, mitochondrial transmembrane potential; PTP, permeability transition pore; cyt $c$, cytochrome $c$; CCCP, carbonyl cyanide $m$-chlorophenylhydrazone; STP, staurosporine; DGX, digoxigenin; MTO, MitoTracker Orange; Adx, adrenodoxin
\end{abstract}

\section{Introduction}

In addition to their functional roles in cellular energy production and $\mathrm{Ca}^{2+}$ homeostasis, mitochondria in mammalian cells have emerged as important players in the integration and execution of the intrinsic apoptotic pathway. ${ }^{1-6}$ Mitochondria amplify the apoptotic signals by releasing proteins such as cytochrome $c$ and Smac from the mitochondrial intermembrane and matrix compartments, respectively, that together help execute the apoptotic signal. ${ }^{7,8}$ Release of cytochrome $c$ (cyt $c$ ) is a critical step in the propagation of apoptotic signal in cells exposed to various physiological and pathological stimuli including UV radiation, increased $\left[\mathrm{Ca}^{2+}\right]_{\mathrm{C}}$, reactive oxygen species, serum withdrawal, immunosuppressive and other drugs, or anoxia. ${ }^{9-11}$ The precise biochemical steps involved in the release of cyt $c$ from mitochondria remain unclear, although the permeability transition pore (PTP) opening is thought to be a key step in this process. The PTP opening in turn is enhanced by the association of homo- or hetero-dimeric forms of proapoptotic proteins such as Bax, Bak, BAD, and Bid with the mitochondrial membrane, which is inhibited by antiapoptotic proteins like $\mathrm{Bcl}-2$ and $\mathrm{Bcl}-\mathrm{X}_{\mathrm{L}}{ }^{12}$ (see reviews). ${ }^{5,13,14}$ It has also been suggested that mitochondrialtargeted Raf-1 kinase modulates the activity of proapoptotic proteins by phosphorylation, thereby rendering protection against apoptosis induced by intrinsic signals. ${ }^{15-17}$

Some studies show a close association between the release of cyt $c$ from mitochondria in response to apoptotic stimuli and collapse of mitochondrial transmembrane potential, $\Delta \Psi_{\mathrm{m} \cdot}{ }^{18,19}$ These observations led to the belief that disruption of $\Delta \Psi_{\mathrm{m}}$ is a necessary step in the release of cyt $c$, and thus execution of apoptosis. More recent studies using various established tumor cell lines, however, show that disruption of $\Delta \Psi_{\mathrm{m}}$ either by mitochondrial DNA (mtDNA) depletion or by metabolic inhibitors alone is not sufficient for cyt $c$ release and execution of apoptotic signal. ${ }^{1,20-22}$ Currently, there is increasing and compelling evidence that PTP opening is the key step leading to cyt $c$ release. However, since PTP opening is often coupled with the collapse of $\Delta \Psi_{\mathrm{m}}$, it is difficult to establish clearly the precise order of these two events and their causal relationship with cyt $c$ release.

Recent studies from our laboratory showed that disruption of $\Delta \Psi_{\mathrm{m}}$ either by treatment with mitochondrial-specific ionophore, carbonyl cyanide $m$-chlorophenylhydrazone (CCCP), ${ }^{23}$ or mtDNA depletion by treatment with low concentrations of ethidium bromide ( $\mathrm{EtBr})$ in $\mathrm{C} 2 \mathrm{C} 12$ myocytes and $A 549$ cells causes activation of stress signaling cascade, which we designated as mitochondria-to-nucleus stress signaling. ${ }^{23-25}$ The stress signaling is propagated through increased cytoplasmic $\mathrm{Ca}^{2+}$, activation of calcineurin as well as other $\mathrm{Ca}^{2+}$-dependent factors. The stress signaling is reversible by restoration of $\Delta \Psi_{\mathrm{m}}$, and characterized by altered expression of an array of nuclear genes and altered cell morphology. ${ }^{24,25}$ Interestingly, both $\mathrm{C} 2 \mathrm{C} 12$ myocytes and A549 cells subjected to mitochondrial stress show vastly increased invasive behavior in both in vitro Matrigel system and in vivo xenotransplantation assay systems. ${ }^{24,25}$ Consistent with the phenotypic changes and invasive 
property of cells, ${ }^{24,25}$ the present study shows that $\mathrm{C} 2 \mathrm{C} 12$ rhabdomyoblasts and A549 lung carcinoma cells also acquire marked resistance to apoptosis in response to mitochondrial stress.

Since resistance to apoptosis is hallmark of cancer cells at advanced stages of tumor progression, and cells with acquired resistance to cytotoxic drugs, we investigated the mechanism of mitochondrial stress-mediated resistance to apoptosis in $\mathrm{C} 2 \mathrm{C} 12$ myocytes. Our results show that although a number of proapoptotic markers, including Bax, BAD, and Bid are induced during mitochondrial stress, these cells are resistant to staurosporine (STP)-mediated cyt $c$ release because of multiple factors including mislocalization of BAD, Bax and Bid to mitochondrial inner membrane compartment where they are not accessible for interaction with $\mathrm{Bcl}-2$, and inability to process Bid.

\section{Results}

\section{Resistance to staurosporine-induced cell death in mtDNA-depleted $\mathrm{C} 2 \mathrm{C} 12$ cells}

Figure 1a shows the Southern blot analysis of mitochondrial DNA from control and mtDNA-depleted $\mathrm{C} 2 \mathrm{C} 12$ cells. It is seen that mtDNA content of depleted cells is about $20 \%$ of control cells. The immunoblot in Figure $1 \mathrm{~b}$ shows that consistent with the mtDNA contents, the levels of mitochondrial genome coded COX I protein in depleted cells is reduced by about 80 $90 \%$ as compared to control cells. Cell cultures representing these mtDNA contents were used in all the experiments described in this paper.

STP, a general inhibitor of protein kinase, is also a potent inducer of apoptosis. As shown in Figure 2a, mtDNA-depleted C2C12 cells were generally resistant to STP-induced apop-

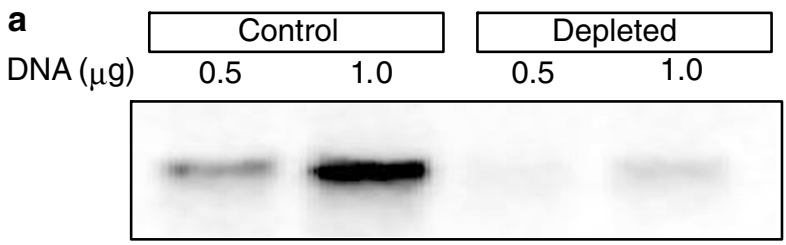

b



Figure 1 Mitochondrial DNA contents and mitochondrial encoded protein levels in control and mtDNA-depleted cells. (a) Southern blot hybridization of mitochondrial DNA. Indicated amounts of total cellular DNA digested with Bg/ II were subjected to Southern blot hybridization with ${ }^{32} \mathrm{P}$-labeled mouse COX I/ COX II DNA probe. Hybridization conditions were as described before. ${ }^{23}$ (b) Immunoblot analysis of total mitochondrial protein (30 $\mu \mathrm{g}$ each) from control and mtDNA-depleted cells using COX I-specific monoclonal antibody. The blot was stripped and reprobed with antibody to mitochondrial-specific marker protein, Adx to assess the levels of proteins loaded tosis ( $2 \mu \mathrm{M}$ of STP for $4 \mathrm{~h}$ ). It is seen that only about $12-14 \%$ of cells are undergoing apoptosis (middle panels), compared to $>80 \%$ cells in control untreated cells (top panels) as measured by TUNEL assay. Cells undergoing apoptosis uniformly exhibited condensed nuclei and also more dispersed nuclear staining indicative of extensive DNA strand breaks. Interestingly, reverted cells in which the mtDNA content is brought back to nearly $90 \%$ of the normal cell level show STP-induced apoptosis closer to the control cells $(>65 \%)$. These results show that resistance to apoptosis in these cells is directly linked to mitochondrial stress due to reduced mtDNA content.

We further evaluated the effect of STP on cyt $c$ release in control and mtDNA-depleted cells by immunohistochemistry using antibody to cyt $c$. Immunohistograms in Figure $2 b$ show a time-dependent release of cyt $c$ into the cytosol of control cells treated with STP as depicted by the diffused staining pattern as opposed to staining of punctate mitochondria-like structures in cells not treated with STP. In control cells treated with STP for 2 and $4 \mathrm{~h}$, there was a gradual reduction in the size of nuclei as well as the cytoplasmic compartment. In contrast, mtDNA-depleted cells (lower panel) were relatively refractory to the apoptotic effects of STP. Both the staining of granular structures and the size/shape of nuclei remain relatively unaltered in mtDNA-depleted cells even at $4 \mathrm{~h}$ of STP treatment. Immunoblots in Figure 2c essentially support these observations. It is seen that the levels of both cyt $c$ and Smac in the cytoplasmic compartment increased sharply in control cells treated with STP compared to cells not exposed to the drug. In mtDNA-depleted cells, however, STP treatment failed to cause an increase in the cytoplasmic levels of both cyt $c$ and Smac. Immunoblots with antibody to cytosolic marker protein actin, and mitochondrial-specific marker protein Adx (last two panels) indicate the relative purity of the subcellular fractions. Adx is a nuclear coded mitochondrial matrix protein whose content does not vary in response to mitochondrial stress. These results together show that mtDNA-depleted $\mathrm{C} 2 \mathrm{C} 12$ cells are relatively resistant to STP-mediated apoptosis.

\section{Effect of STP on mitochondrial membrane potential}

As shown in our previous studies, ${ }^{23-25}$ the mtDNA-depleted C2C12 myocytes and A549 cells exhibited markedly reduced $\Delta \Psi_{\mathrm{m}}$ and respiration-driven ATP generation. In the present study, we investigated the effect of STP treatment on $\Delta \Psi_{\mathrm{m}}$ of normal and mtDNA-depleted cells (Figure 3). The mitochondrial membrane potential as measured by fluorescence of MTO dropped steadily at 2 and $4 \mathrm{~h}$ of treatment of cells with STP (Figure 3a). At $6 \mathrm{~h}$ of STP treatment, there was a small recovery of $\Delta \Psi_{\mathrm{m}}$. The mtDNA-depleted cells, on the other hand, showed a consistently low MTO uptake both before and after STP treatment (Figure $3 \mathrm{~b}$ ) indicating vastly disrupted $\Delta \Psi_{\mathrm{m}}$. At $2 \mathrm{~h}$ of STP treatment, however, the mtDNA-depleted cells showed a transient recovery of $\Delta \Psi_{\mathrm{m}}$. The reason for this recovery remains unknown, although it may represent an adaptive response to the drug through efflux or influx of ions, ATP (in)/ADP (out) exchange or overproduction of ROS. ${ }^{34-36}$ 
a
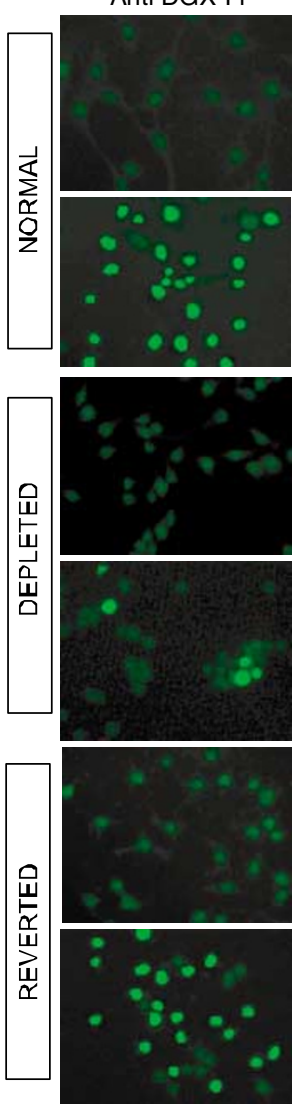

DAPI
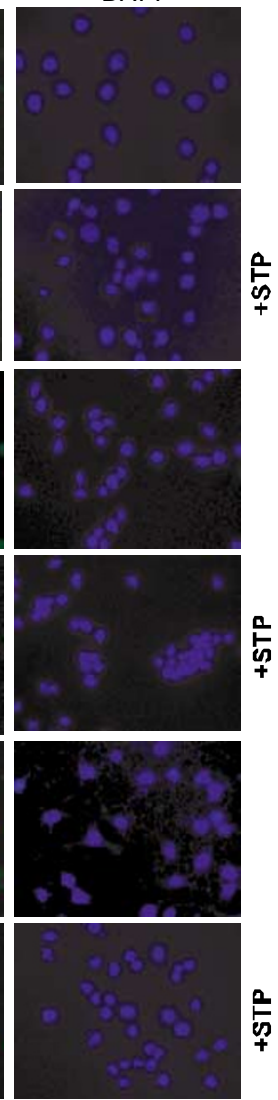

b

STP

oh



$2 h$

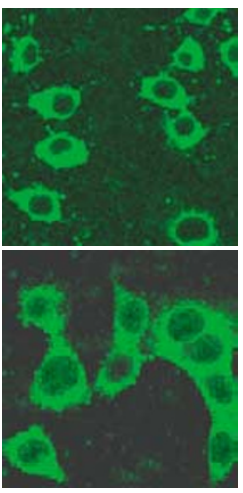

$4 h$

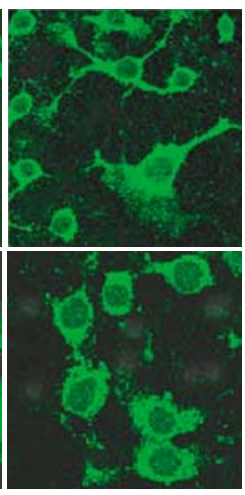

C

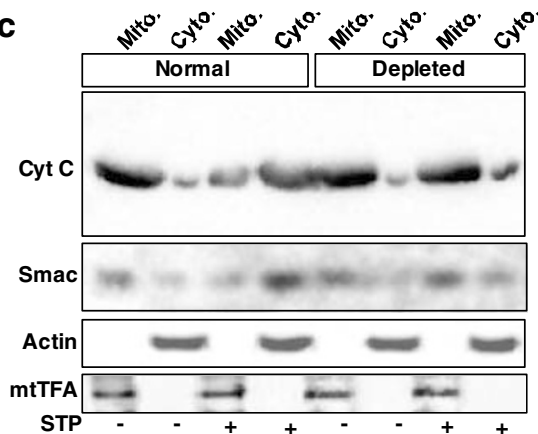

Figure 2 Causal relationship between depletion of mtDNA and resistance to staurosporine (STP)-induced apoptosis in C2C12 rhabdomyocytes. (a) Control, mtDNAdepleted and reverted $\mathrm{C} 2 \mathrm{C} 12$ myocytes were treated with $2 \mu \mathrm{M}$ STP. Staining with FITC-conjugated anti-DGX (anti-DGX-FI) for TUNEL assay, counter staining with DAPI, and details of microscopy were as described in the Materials and Methods section. (b) Control and mtDNA-depleted cells were subjected to STP treatment (2 $\mu \mathrm{M}$ ) for indicated time periods, stained with FITC conjugated anti-cyt $c$ and viewed under fluorescence microscope. (c) Immunoblot analysis of mitochondrial and cytosolic proteins $(30 \mu \mathrm{g}$ each) from control and mtDNA-depleted $\mathrm{C} 2 \mathrm{C} 12$ cells. Companion blots were developed with antibody to cyt $c$ and Smac. The same two blots were stripped and developed either with antibody to Adx or $\beta$-actin for assessing loading levels

Reverted cells containing nearly $90 \%$ of the control cell mtDNA content showed MTO uptake closer to the control cells suggesting restored $\Delta \Psi_{\mathrm{m}}$ (results not shown). These results show that STP treatment causes disruption of $\Delta \Psi_{\mathrm{m}}$ in control cells and that the mtDNA-depleted cells exhibit vastly disrupted $\Delta \Psi_{m}$ even in the absence of added STP.

\section{Resistance to STP-mediated apoptosis and activation of caspases in mtDNA-depleted C2C12 cells}

Since treatment of control C2C12 cells with STP for $4 \mathrm{~h}$ showed markedly reduced $\Delta \Psi_{\mathrm{m}}$ and loss of cyt $c$, in all subsequent experiments, this same STP treatment conditions were used for all cell types. As shown in Figure $4 a$, the mitochondrial contents of proapoptotic proteins, Bax, Bid and BAD were markedly increased in control and reverted cells following treatment with STP. The levels of these proteins in the cytoplasmic compartment were correspondingly reduced (results not shown), suggesting increased translocation to the mitochondrial compartment following STP treatment. In the case of Bid, there was also an extensive processing of $21 \mathrm{kDa}$ precursor to active $17 \mathrm{kDa}$ tBid (p17 tBid) in both the mitochondrial and cytoplasmic (results not shown) compartments. The latter is believed to be a required step for the propagation of extrinsic signal. In reverted cells, there was even a higher extent of Bid processing confirming a relationship between mtDNA content and p17 tBid formation in these cells. The mtDNA-depleted cells, and also control cells treated with $\mathrm{CCCP}$, on the other hand, contained a generally elevated mitochondrial Bax, Bid and BAD. The cytosolic levels of these proteins were marginally elevated suggesting an overall cellular increase in the steady-state levels of these proteins under mitochondrial stress conditions. Furthermore, in both mtDNA-depleted and CCCP-treated cells, STP treatment did not cause a significant increase of these proteins either in the mitochondrial or cytosolic compartments (the latter results not shown). In marked difference from the patterns with control and reverted $\mathrm{C} 2 \mathrm{C} 12$ cells, however, mtDNA-depleted cells and also CCCP-treated cells showed no detectable processing of p21 Bid to p17 tBid even after STP treatment. The levels of $\mathrm{Bcl}-\mathrm{X}_{\mathrm{S}}$ did not change significantly either by mtDNA depletion or CCCP treatment. STP treatment increased the 

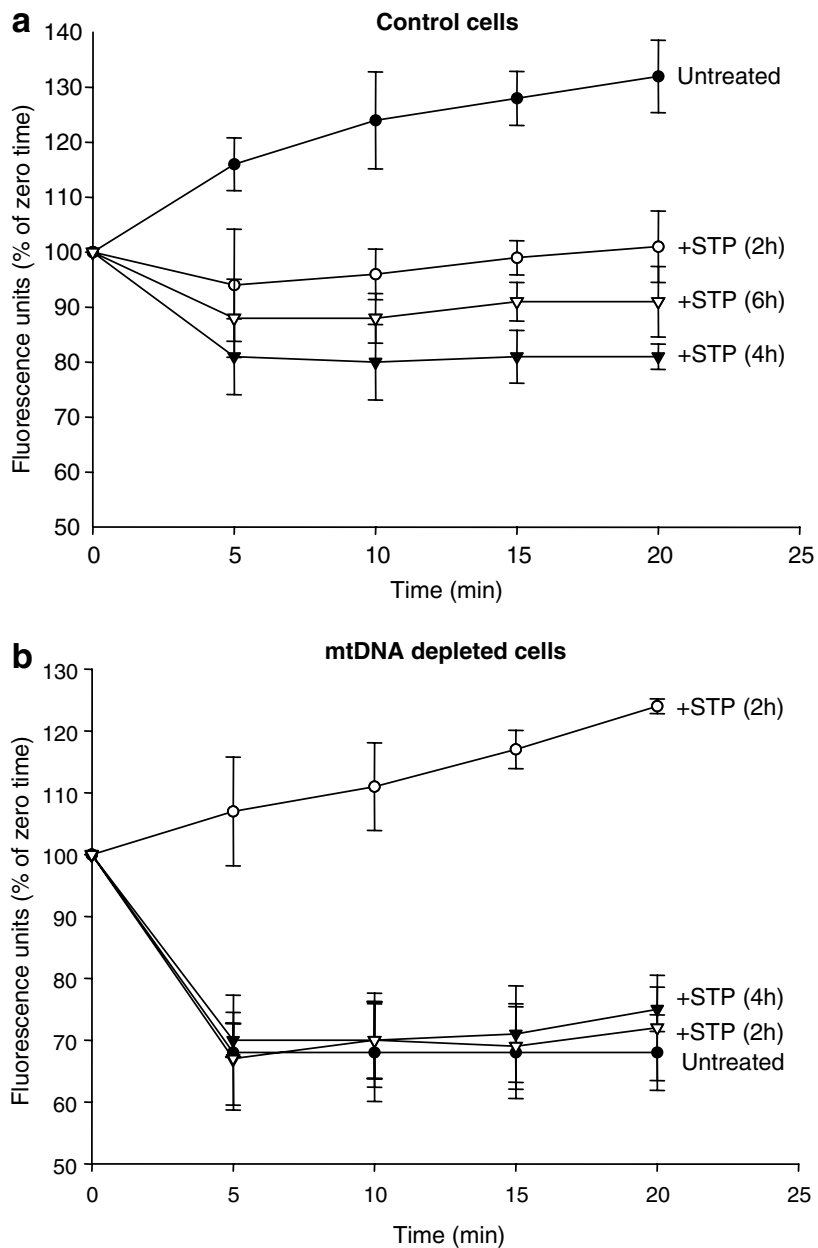

Figure 3 Disruption of mitochondrial $\Delta \psi_{\mathrm{m}}$ by STP treatment: (a) control and (b) mtDNA-depleted $\mathrm{C} 2 \mathrm{C} 12$ cells. Time-dependent uptake of MTO by cells treated with STP $(2 \mu \mathrm{M})$ for 2,4 and $6 \mathrm{~h}$ and untreated cells was measured as described in the Materials and Methods section. The initial fluorescence at zero time with each cell type was considered $100 \%$ for calculating the $\%$ change at different time points of incubation. Average \pm S.D. were calculated from 4-6 measurements

level of $\mathrm{Bcl}-\mathrm{X}_{\mathrm{S}}$ in both control and reverted cells. However, STP treatment caused a lower steady-state level of $\mathrm{Bcl}-\mathrm{X}_{\mathrm{S}}$ in mtDNA-depleted and CCCP-treated cells. The relative levels of Adx used as loading control for the mitochondrial compartments, showed no significant change under these experimental conditions.

Immunoblot in Figure $4 \mathrm{~b}$ shows that the mitochondrial levels of antiapoptotic proteins $\mathrm{Bcl}-2, \mathrm{Bcl}-\mathrm{X}_{\mathrm{L}}$ and cytoplasmic level of Survivin were markedly increased in mtDNA-depleted cells as well as in cells subjected to chemical stress by treatment with $\mathrm{CCCP} .{ }^{23}$ The reverted cells showed significantly reduced, albeit higher than control cellular level of $\mathrm{Bcl}-$ 2. However, similar to its proapoptotic product $\mathrm{Bcl}-\mathrm{X}_{\mathrm{S}}$, the levels of $B c l-X_{L}$ did not increase in cells subjected to mitochondrial stress either by mtDNA depletion or CCCP treatment. In control and reverted cells, the mitochondrial level of $\mathrm{Bcl}-2$ and $\mathrm{Bcl}-\mathrm{X}_{\mathrm{L}}$ were reduced by STP treatment, but that of $\mathrm{Bcl}-\mathrm{X}_{\mathrm{S}}$ was increased. In both mtDNA-depleted and
CCCP-treated cells, Bcl-2 level was increased $~ 3-4$-fold, while the levels of $\mathrm{Bcl}-\mathrm{X}_{\mathrm{L}}$ was marginally reduced by STP treatment. The cytoplasmic level of antiapoptotic protein, Survivin increased 2-3-fold in mtDNA-depleted cells, which returned to near-control cell level in reverted cells. However, the level of this protein was only marginally increased in CCCP-treated cells. Furthermore, similar to the levels of other antiapoptotic proteins, the level of Survivin was reduced by STP treatment in both control and reverted cells, but remained unchanged in mtDNA-depleted and CCCP-treated cells. Results in Figure $4 a$ and $b$ therefore, show that the steadystate levels of Bcl-2 and Survivin and also the extent of processing of p21 Bid were nearly completely reversed in reverted cells which respond to STP-mediated apoptosis. Reversibility of protein levels and processing activity in reverted cells suggests a direct relationship of these processes with mitochondrial stress.

To understand the mechanism of reversible resistance to STP-mediated apoptosis in mtDNA-depleted cells, we next investigated the steady-state levels of both upstream as well as downstream caspases and their activation. It is seen from Figure 5 that total cell extracts from control, mtDNA-depleted, reverted, and also CCCP-treated $\mathrm{C} 2 \mathrm{C} 12$ cells contain comparable levels of intact procaspases 3, 9 and 8. Control and reverted cells treated with STP show faster migrating components characteristic of activated caspases. In the case of mtDNA-depleted and CCCP-treated cells, however, STP treatment did not cause activation of any of the three caspases tested. These results provide confirmatory evidence that mtDNA-depleted cells are unable to execute the STP-mediated apoptotic signal.

\section{Topological orientation of proapoptotic proteins}

Our results show that despite the general increase of proapoptotic proteins in the mitochondrial membrane compartment the mtDNA-depleted cells and CCCP-treated cells resist cyt $c$ release and caspase activation when treated with STP. We therefore sought to examine the precise intramitochondrial location and membrane topology of proapoptotic proteins, Bid, BAD and Bax. Mitochondria from STP-treated and untreated cells were subjected to limited digestion with trypsin (30 $\mu \mathrm{g} / \mathrm{mg}$ protein) to see if the proteins are loosely bound to the outer membrane or integrated in the membrane. Another set of mitochondrial preparations were treated with digitonin ( $75 \mu \mathrm{g} / \mathrm{mg}$ mitochondrial protein) to strip out the outer membrane for determining the distribution of proteins between the inner and outer membranes. As seen from Figure 6, in both STP-treated and untreated control cells (left panel, lanes 1-6), Bax, Bid and BAD show protection against trypsin digestion (lanes 2 and 5). As observed in Figure 4a, STP treatment invariably increased the mitochondrial contents of all the three proteins. These results dispel the possibility that the proteins are loosely associated with mitochondrial outer membrane. Digitonin treatment of mitochondria from both STP-treated and untreated cells (lanes 3 and 6) vastly reduced the levels of all three proteins suggesting that they are mostly localized in the outer membrane. In the case of both mtDNA-depleted and CCCP-treated cells, however, all three proteins were resistant to digitonin treatment suggesting 
a
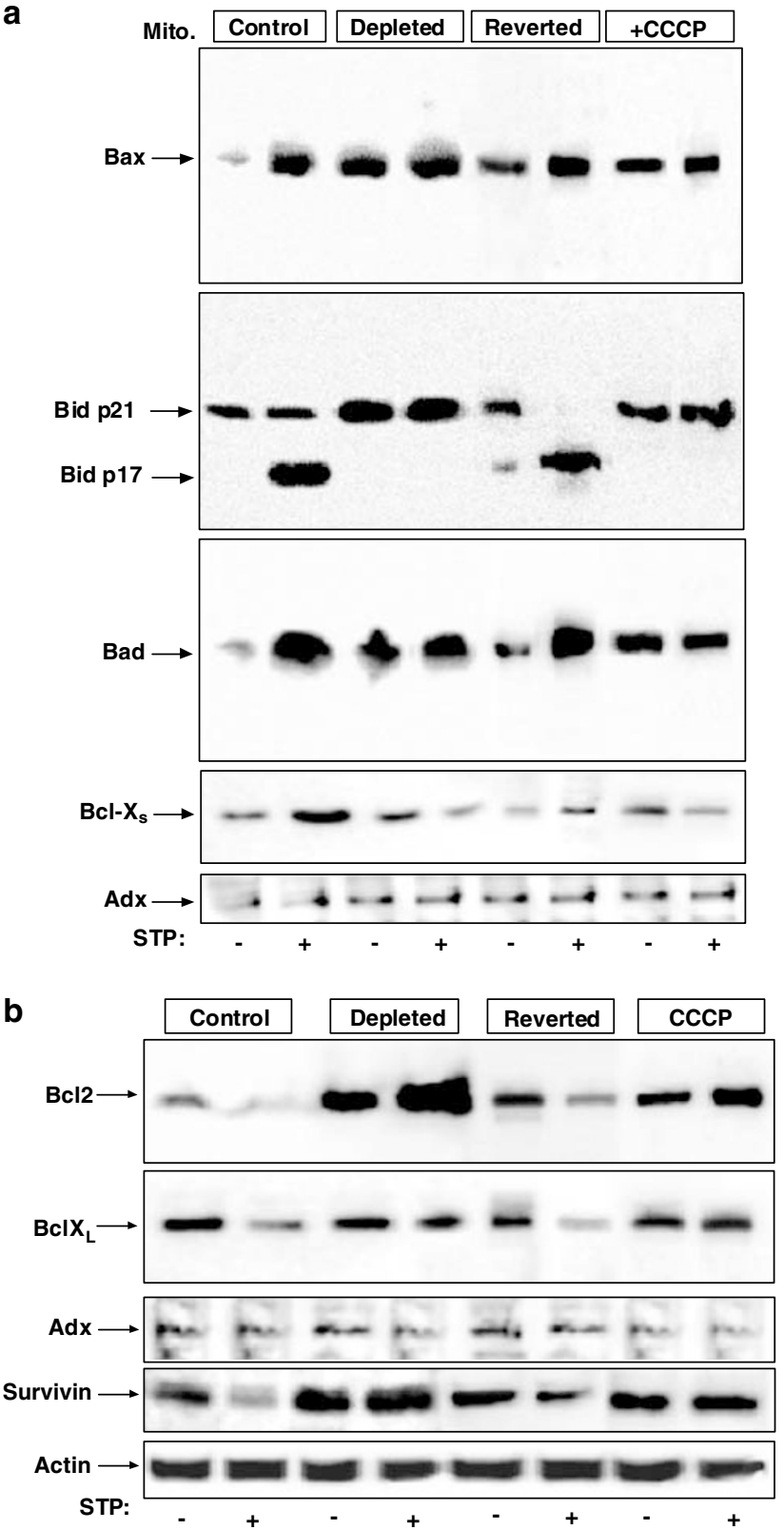

Figure 4 Distinctive effects of STP on the levels of pro- and antiapoptotic proteins in control and mtDNA-depleted $\mathrm{C} 2 \mathrm{C} 12$ cells: (a) mitochondrial and cytosolic proteins (30 $\mu \mathrm{g}$ each) from control, mtDNA-depleted, reverted and CCCP $(25 \mu \mathrm{M}$ for $4 \mathrm{~h})$ treated cells were resolved by SDS-polyacrylamide gel electrophoresis as described in the Materials and Methods section and three representative blots were probed with antibodies to BAX, Bid and Bad as indicated. The blots were stripped and reprobed with antibody to $\mathrm{Adx}$ to determine the loading levels. (b) In top two panels, mitochondrial protein $(30 \mu \mathrm{g}$ each) from control, mtDNA-depleted, reverted and CCCP $(25 \mu \mathrm{M}$ for $4 \mathrm{~h})$ treated cells were subjected to immunoblot analysis with antibodies to Bcl-2 and Bcl- $\mathrm{X}_{\mathrm{L}}$. The gels were stripped and reprobed with antibody to Adx. Although both blots showed similar Adx staining patterns, only one is presented in the third panel from top. In the fourth panel, cytosolic proteins ( $25 \mu \mathrm{g}$ each) from indicated cell types were subjected to immunoblot analysis with antibody to Survivin. The blot was stripped and reprobed with antibody to $\beta$-actin

their inner membrane localization. Additionally, as shown before in Figure $4 \mathrm{a}$, there was no detectable p17 tBid in both mtDNA-depleted and CCCP-treated cells indicating a loss of processing activity. These results show a distinctly different membrane organization of the three proapoptotic proteins in cells subjected to mitochondrial stress either by mtDNA depletion or CCCP treatment.

Reduced phosphorylation of proapoptotic proteins in STPtreated cells is regarded as an important factor in proteinprotein interaction and heterodimerization of membraneassociated proapoptotic proteins. We therefore studied the level of phosphorylated BAD in STP treated and untreated control and mtDNA-depleted cells. In Figure 7a, immunoprecipitated BAD from the total mitochondrial membrane and cytoplasmic fractions was subjected to immunoblot analysis with anti phospho-Ser antibody. Results show that in control C2C12 cells, only the cytosolic BAD was phosphorylated at detectable level that was aborted by STP treatment. The mitochondrial membrane-associated BAD, in both STPtreated and untreated cells, was not phosphorylated. In the case of mtDNA-depleted cells, however, both mitochondrial and cytoplasmic BAD was phosphorylated at comparable levels, and STP treatment had no effect on the level of phosphorylation suggesting that these proteins are refractory to the action of protein phosphatase. As shown in Figure 7b, the inner membrane-associated BAD in mtDNA-depleted cells treated with or without STP was not phosphorylated. These results not only show an altered membrane topology, but also an altered phosphorylation pattern of proapoptotic proteins in cells subjected to mitochondrial stress. Results in Figure 7c show that AKT level is increased in mtDNA-depleted cells as a possible reason for phosphorylation of mitochondria-associated BAD protein.

\section{Effects of overexpression of $\mathrm{Bcl}-2$ and altered Bid processing on resistance to apoptosis}

Acquired resistance to apoptosis in cells subjected to mitochondrial stress may either be due to overexpression of antiapoptotic protein $\mathrm{Bcl}-2$ or inability to process proapoptotic protein Bid. We investigated this possibility by assessing the effect of Bcl-2-specific inhibitor HA14-1. ${ }^{37}$ As shown in Figure 8a, a combination of HA14-1 and STP induced apoptosis in control $\mathrm{C} 2 \mathrm{C} 12$ cells (top two panels). With mtDNA-depleted cells, HA14-1 alone had no effect, while cells exposed to both STP and HA14-1 showed $5-6 \%$ of cells undergoing apoptosis. This level is similar to the level obtained with STP alone in Figure 2a indicating that HA14 addition had no significant effect on the STP-mediated apoptosis in mtDNA-depleted cells. These results suggest that overexpressed $\mathrm{Bcl}-2$ in mtDNA-depleted cells may not be the cause of resistance to STP-induced apoptosis.

Caspase 8-mediated processing of p21 Bid is thought to be another critical step in the execution of some apoptotic signals. Specifically, activated $\mathrm{p} 17 \mathrm{tBid}$ is thought to induce membrane permeability by heterodimerization with other channel-forming proteins in the outer membrane such as $B A D$ and Bax. ${ }^{38-40}$ We therefore investigated the effects of added tBid to mitochondria from different sources on cyt $c$ release. It is seen from Figure $8 b$ (lanes 1-3) that isolated mitochondria from control, depleted and reverted cells did not release detectable levels of cyt $c$ by in vitro incubation without 

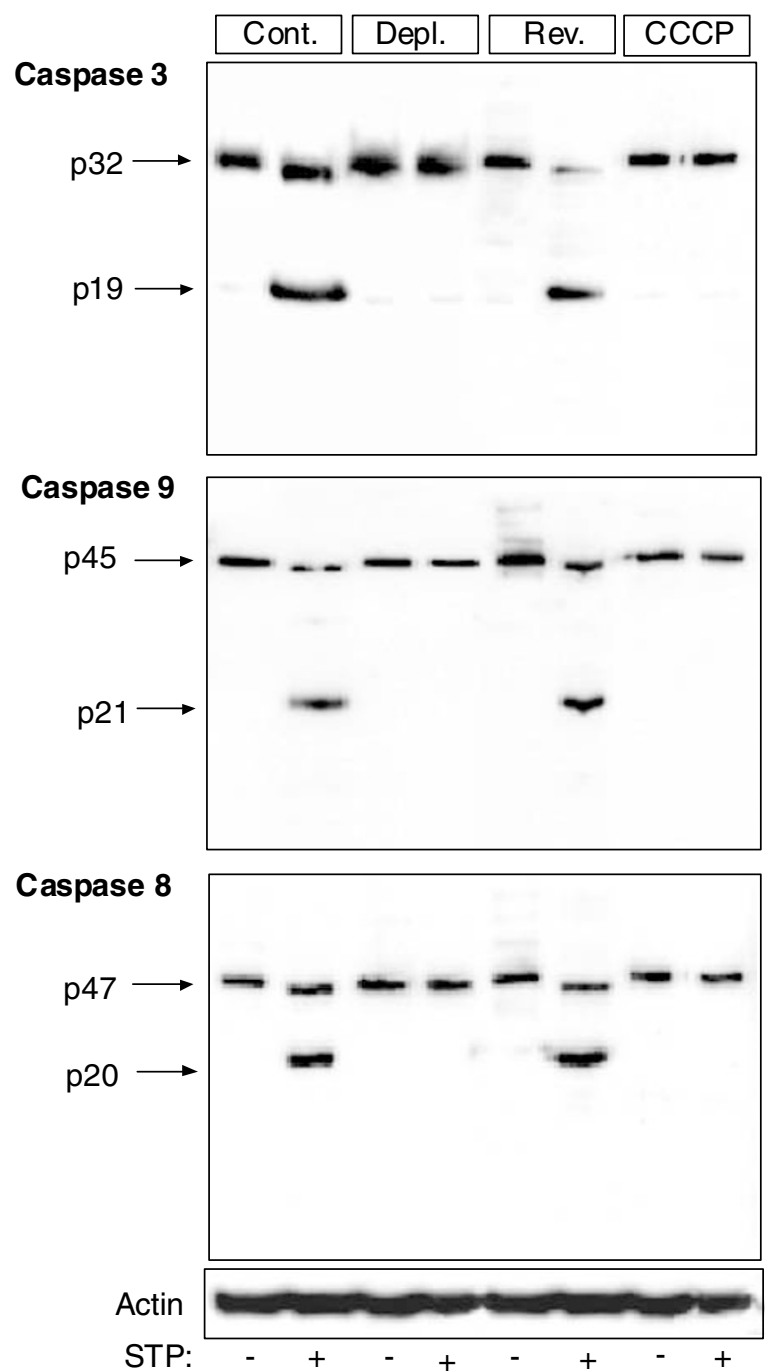

Figure 5 Effects of STP and mitochondrial stress on the activation of various caspases. Cytosolic proteins ( $30 \mu \mathrm{g}$ each) from control, mtDNA-depleted, reverted, and CCCP ( $25 \mu \mathrm{M}$ for $4 \mathrm{~h})$ treated cells were subjected to immunoblot analysis. Three identically run blots were probed with antibodies to caspases 3,9 and 8 as indicated. The blots were stripped and reprobed with antibody to $\beta$ actin. All three blots yielded similar patterns with $\beta$-actin antibody, though only one of them is presented. Treatment with STP was as described in Figure 2

added tBid. Addition of $25 \mathrm{nM}$ tBid caused cyt $c$ release in mitochondria from both control and reverted cells. It is also seen that addition of tBid caused cyt $c$ release from mtDNAdepleted cell mitochondria in a concentration-dependent manner. As expected, cytosolic fraction from control cells failed to release cyt $c$ from $\mathrm{mtDNA}$-depleted cell mitochondria. Cytosol from STP-treated $\mathrm{C} 2 \mathrm{C} 12$ cells, which contain processed p17 tBid, (results not shown), however, induced cyt $c$ release. A similar dose-dependent increase in cyt $c$ release was observed by adding the cytosolic protein from STP-treated cells depleted of cyt $c$. These results suggest that loss of caspase 8-mediated processing of p21 Bid may be a critical factor in the inability of mtDNA-depleted $\mathrm{C} 2 \mathrm{C} 12$ cells to execute STP-induced apoptotic signal.

\section{Discussion}

It is well established that mitochondria not only help integrate and amplify both extrinsic and intrinsic apoptotic signals, but also execute cell death by releasing various proapoptotic proteins including cyt $c$, Smac/DIABLO and procaspases to the cytoplasm. Among the many mechanisms proposed, the more widely accepted one implies that the relative abundance of the pro- and antiapoptotic Bcl-2 family proteins in the mitochondrial membrane and their molecular interactions control the release of cyt $c$ and other proapoptotic proteins. ${ }^{5,13,41-44}$ Specifically, association of $\mathrm{Bcl}-2$ with proapoptotic tBid, BAD, and Bax renders protection against apoptosis. On the other hand, a stoichiometric increase in the levels of proapoptotic proteins or their release from Bcl-2 leading to hetero- or homodimerization with Bid is a dominant factor in the execution of death signals. ${ }^{45,46}$ Some studies suggest that the proapoptotic proteins form an ordered cluster on the outer membrane as pores or channels thus releasing cyt $c,^{5,47}$ which in turn perturbs the inner membrane and causes the collapse of $\Delta \Psi_{\mathrm{m}}$. Other studies imply that proapoptotic proteins may induce PTP by direct interaction with voltagedependent anion channel (VDAC) and adenine nucleotide translocator (ANT), thus causing the release of proapoptotic proteins from both mitochondrial matrix and intermembrane space. ${ }^{41-44}$ In this study, we show that impaired Bid processing and altered targeting of proapoptotic proteins to mitochondrial inner membrane under mitochondrial stress conditions impart resistance to apoptosis.

Results presented in this paper show that both mitochondrial genetic stress (loss of $\Delta \Psi_{\mathrm{m}}$ due to mtDNA depletion) and chemical stress (loss of $\Delta \Psi_{\mathrm{m}}$ by treatment with mitochondrial ionophore, CCCP) in $\mathrm{C} 2 \mathrm{C} 12$ myocytes induce the steadystate levels of antiapoptotic protein $\mathrm{Bcl}-2$, and Survivin and proapoptotic proteins BAD, Bid and Bax. Despite the induced levels of various apoptotic markers and vastly reduced $\Delta \Psi_{\mathrm{m}}$, under the mitochondrial stress conditions, both $\mathrm{C} 2 \mathrm{C} 12$ myocytes and A549 lung carcinoma cells (the latter results not shown) developed resistance to STP-mediated cell death. We also observed that under stress conditions, the cellular activity for processing p21 Bid was vastly reduced, in addition to markedly increased levels of mitochondrial Bcl-2, Bid, BAD and Bax. Notably, all the three proapoptotic proteins were predominantly partitioned to the inner membrane, while Bcl-2 was mostly localized on the outer membrane. Furthermore, inner membrane-associated BAD was mostly unphosphorylated, while the relatively smaller pool of BAD associated with the outer membrane was phosphorylated. Our results show that despite a markedly increased antiapoptotic Bcl-2, its specific inhibitor, HA14-1 had no significant effect on STPmediated apoptosis in mtDNA-depleted cells probably because of physical separation of anti- and proapoptotic proteins. The nature of pro- and antiapoptotic proteins induced, their intramitochondrial locations, and the effects of various inhibitors are listed in Table 1.

Processing of $21 \mathrm{kDa}$ Bid protein to an active C-terminal $17 \mathrm{kDa}$ tBid is regarded as an important step in the signal amplification of the extrinsic pathway such as that initiated by TNF $\alpha$. It is believed that caspase 8- or myristoylationmediated $^{48}$ processing helps targeting tBid to mitochondrial 


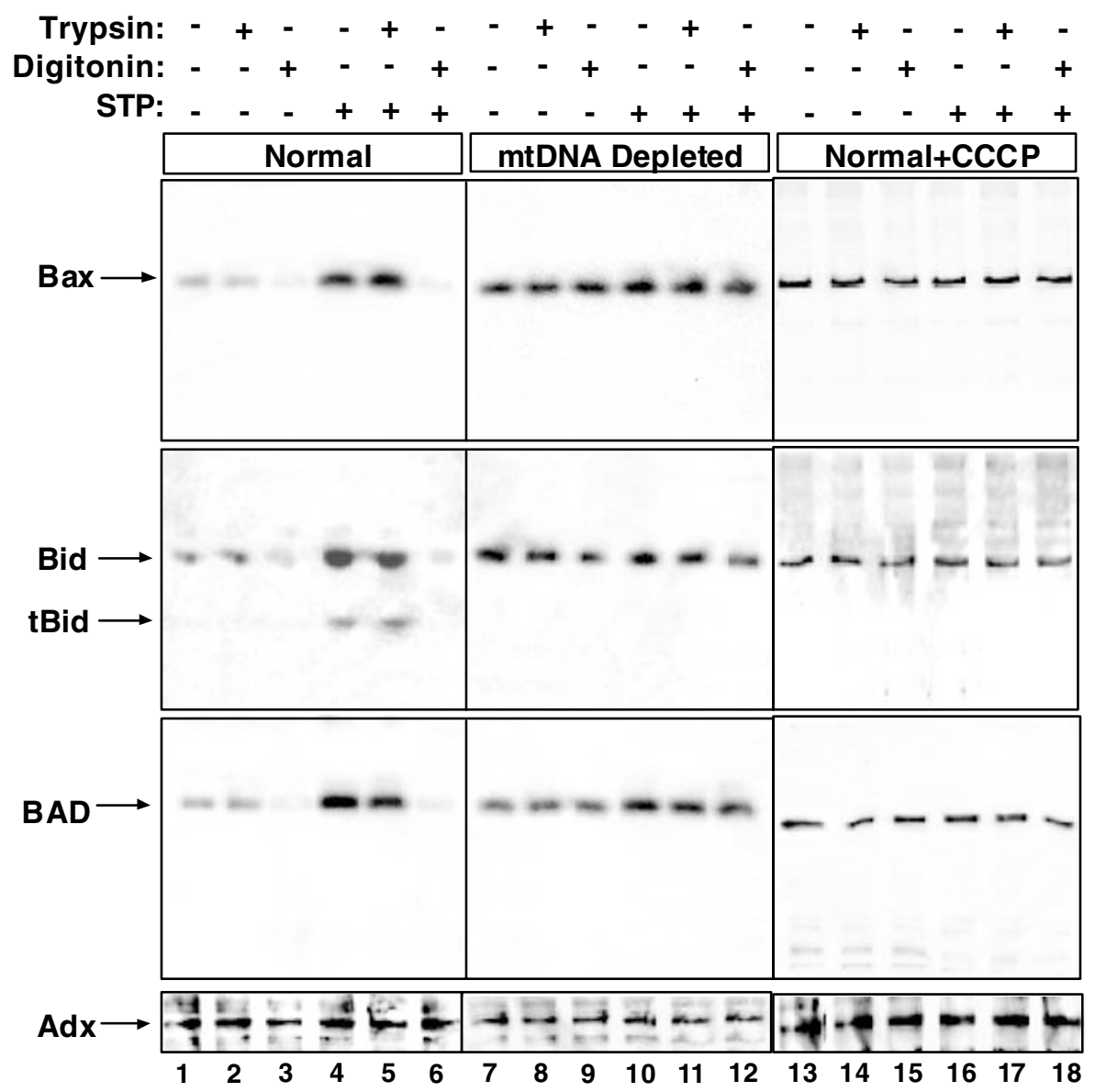

Figure 6 Different topological organization of proapoptotic proteins in control $\mathrm{C} 2 \mathrm{C} 12$ cells and cells subjected to mitochondrial stress. Mitochondria from control and mtDNA-depleted cells, or cells treated with CCCP $(25 \mu \mathrm{M}$ for $4 \mathrm{~h})$ treated with or without STP were subjected to trypsin or digitonin treatment as described in the Materials and Methods section. Proteins $(25 \mu \mathrm{g})$ from untreated mitochondria, trypsin-treated and digitonin-treated mitochondria were subjected to immunoblot analysis with indicated antibodies. Treatment with STP was as described in Figure 2

outer membrane compartment where it can heterodimerize with members of proapoptotic proteins to form multisubunit channels or pores. It is also known that phosphorylation of tBid and other proapoptotic proteins by Raf1 kinase converts them to inactive forms, thus rendering protection against apoptosis. As part of a mechanism for survival factor induced resistance to apoptosis, some studies show that BAD disassociates from $\mathrm{Bcl}-\mathrm{X}_{\mathrm{L}}$ or $\mathrm{Bcl}-2$ on phosphorylation and gets released to the cytosol, where it is sequestered by $14-3-3$ protein. ${ }^{49-51}$ In cells subjected to mitochondrial stress, however, induced BAD, Bax and Bid were sequestered on the inner membrane (Figure 6) providing a rational basis for the observed resistance to apoptosis. Thus, a grossly altered shuttling of proapoptotic proteins to mitochondrial inner membrane may be a special feature of the mitochondrial stress signaling. Although the precise reasons for the altered protein sequestration remain unclear, vastly reduced ATP production, and or, disrupted transmembrane potential might be responsible.

An important observation of our study relates to the effects of processed tBid on cyt $c$ release (Figure 8 ) by mtDNAdepleted cell mitochondria. Notably, under in vitro conditions, processed tBid or cytosolic fraction from STP-treated cells, which contains tBid, readily induced cyt $c$ release from mitochondria from mtDNA-depleted cells. These results suggest that externally added tBid is able to interact with inner membrane localized BAD and Bax and induce PTP formation. We propose two alternative possibilities to account for the observed tBid-mediated cyt $c$ release: (1) by a yet unknown mechanism, externally added tBid may be targeted to the inner membrane where it associates with proapoptotic proteins. The protein complexes may then be translocated to the outer membrane by shuttling through the inner-outer membrane contact points, where they form functional pores. (2) The added tBid may associate with proapoptotic proteins $\mathrm{BAD}$ and Bax at the inner-outer membrane junctions and the complex then sequesters on the outer membrane to form PTP by an unknown mechanism. Based on the insensitivity of mtDNA-depleted cells to Bcl-2 inhibitor HA14-1, and sensitivity of mitochondria from mtDNA-depleted cells to added tBid, we propose that inability to process p21 Bid into p17 tBid is a major factor in acquired resistance to STP-mediated apoptosis in cells subjected to mitochondrial stress. Based 
a
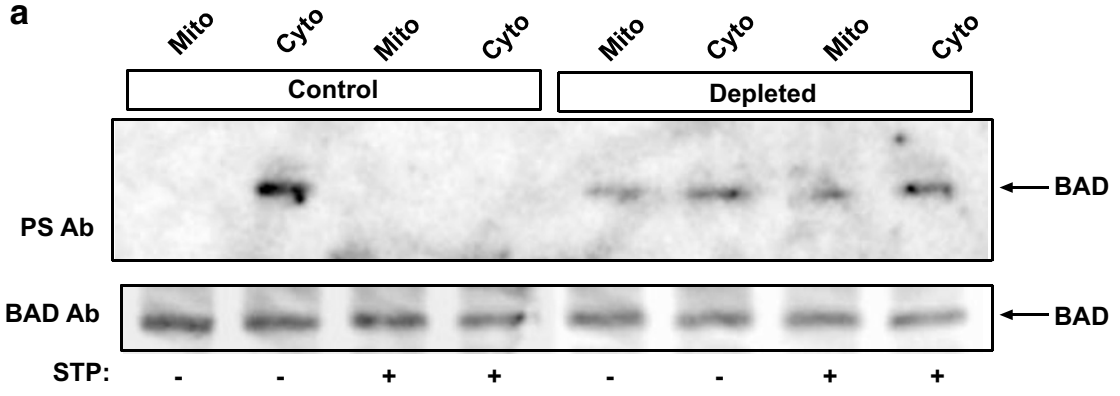

IP: BAD Ab

b

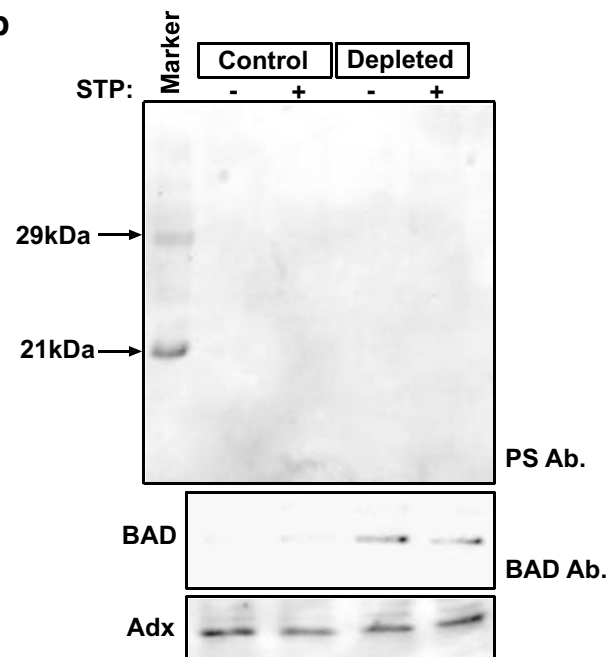

C

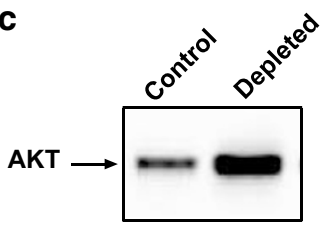

Figure 7 Distinct patterns of phosphorylated BAD in mitochondrial membranes of control and mtDNA-depleted cells. (a) Mitochondrial outer membrane (digitoninsoluble fraction from Figure 6$)$ and cytosolic proteins $(500 \mu \mathrm{g}$ each) from STP-treated and untreated control and mtDNA-depleted cells were immunoprecipitated with polyclonal antibody to BAD. The immunoprecipitates were devided into two equal portions and subjected to electrophoretic resolution on two identical SDSpolyacrylamide gels. One gel was probed with antibody to BAD and the companion gel was probed with antibody to Phospho-Ser. Treatment with STP was as described in Figure 2. (b) Proteins solubilized from digitonin-stripped mitochondria (mitoplasts from Figure 6;500 $\mu \mathrm{g}$ each) were subjected to immunoprecipitation as in (a), and probed with antibody to phosphor-Ser and BAD as described for panel $\mathbf{a}$. The blots were stripped and reprobed with antibody to Adx to assess the loading levels. (c) Postmitochondrial supernatant fractions ( $25 \mu \mathrm{g}$ each) from control and mtDNA-depleted cells were subjected to immunoblot analysis with antibody to AKT

on these results, we propose a hypothetical model (Figure 9) on the mechanism of acquired resistance to apoptosis in C2C12 rhabdomyocytes subjected to mitochondrial stress.

Direct evidence for the role of mitochondrial stress signaling in bringing about the biochemical and phenotypic changes and hence the development of resistance to apoptosis comes from experiments using reverted cells with restored mtDNA content and reestablished $\Delta \Psi_{\mathrm{m}}$. Our results show that reverted cells containing $\sim 90 \%$ mtDNA content of control cells contain Bcl-2, BAD, and Bax protein levels close to control cells. Additionally, the proapoptotic proteins, BAD, Bid and Bax are mostly localized to the outer mitochondrial membrane and remain mostly unphosphorylated in reverted cells in response to STP (results not shown). Accordingly, the reverted cells respond to STP-mediated apoptosis at the level similar to the control cells. These results for the first time establish a direct link between mitochondrial stress, disruption of $\Delta \Psi_{\mathrm{m}}$, and development of resistance to apoptosis. Our results with $\mathrm{C} 2 \mathrm{C} 12$ myocytes and $\mathrm{A} 549$ cells (results not shown) demonstrate that despite the loss of $\Delta \Psi_{\mathrm{m}}$, cells subjected to mitochondrial stress fail to release proapoptotic proteins, cyt $c$ and Smac, and execute the death signal. In this regard, present results show that disruption of $\Delta \Psi_{\mathrm{m}}$ alone is not sufficient to activate PTP as proposed in some models. ${ }^{1,52}$

Studies using cell lines devoid of mtDNA ( $\rho^{\circ}$ cells) from mammalian sources have yielded contradictory results on the possible role of mitochondrial dysfunction in apoptosis. Some studies show that mtDNA depletion and associated mitochondrial structural and functional changes resulted in induced cellular apoptosis. ${ }^{18,19}$ Studies by other groups including ours, ${ }^{23-25,52}$ on the other hand, show that in osteosarcoma, C2C12 rhabdomyoblasts and A549 lung carcinoma cells mtDNA depletion, loss of $\Delta \Psi_{\mathrm{m}}$ and impaired OXPHOS do not contribute to cellular apoptosis. Instead the loss of mtDNA and thus the membrane potential rendered the cells resistant to apoptosis. In osteosarcoma cells, Dey and Moraes ${ }^{52}$ found that overexpression of antiapoptotic protein $\mathrm{Bcl}-2$ in response to mtDNA depletion as the major cause of resistance to apoptosis. In the present study, we show that altered compartmentalization of antiapoptotic proteins on the inner membrane and impaired activity for processing Bid protein as the possible causes of resistance to death signal. 
Table 1 Summary of factors induced and their intramitochondrial location

\begin{tabular}{|c|c|c|c|c|}
\hline & \multicolumn{2}{|c|}{ Control } & \multicolumn{2}{|c|}{ mtDNA depleted } \\
\hline & No STP & STP added & No STP & STP added \\
\hline Cytochrome $c$ release & No & Yes & No & No \\
\hline Smac release & No & Yes & No & No \\
\hline \multicolumn{5}{|c|}{ Levels of Proapoptotic proteins } \\
\hline Bax & $+^{\mathrm{a}}$ & $+++^{\mathrm{C}}$ & +++ & +++ \\
\hline BAD & + & ++++ & ++++ & ++++ \\
\hline Bid & + & ++++ & ++++ & ++++ \\
\hline \multicolumn{5}{|c|}{ Levels of Antiapoptotic proteins } \\
\hline Bcl-2 & + & $-{ }^{\mathrm{b}}$ & ++++ & ++++++ \\
\hline $\mathrm{Bcl}-\mathrm{X}_{\mathrm{L}}$ & + & - & +++ & ++ \\
\hline Survivin & + & - & +++ & +++ \\
\hline \multicolumn{5}{|l|}{ Caspase activation } \\
\hline $\begin{array}{l}\text { Caspase } 8 \\
\end{array}$ & No & Yes & No & No \\
\hline Caspase 9 & No & Yes & No & No \\
\hline Caspase 3 & No & Yes & No & No \\
\hline Induced apoptosis & No & Yes & No & No \\
\hline \multicolumn{5}{|c|}{ Mitochondrial localization of apoptotic proteins } \\
\hline \multicolumn{5}{|c|}{ Outer membrane } \\
\hline Bax & No & Yes & Yes & Yes \\
\hline BAD & No & Yes & Yes & Yes \\
\hline Bid & No & Yes & Yes & Yes \\
\hline \multicolumn{5}{|l|}{ Inner membrane } \\
\hline Bax & No & No & Yes & Yes \\
\hline BAD & No & No & Yes & Yes \\
\hline Bid & No & No & Yes & Yes \\
\hline $\begin{array}{l}\text { BAD phosphorylation } \\
\text { Bid processing }\end{array}$ & Phosphorylated & $\begin{array}{l}\text { Dephosphorylated } \\
\text { Yes }\end{array}$ & Phosphorylated & $\begin{array}{l}\text { Phosphorylated } \\
\text { No }\end{array}$ \\
\hline
\end{tabular}

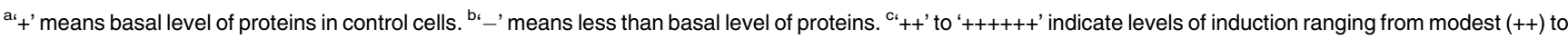
about Six fold $(++++++)$

A large number of studies with mtDNA-depleted tumor cell lines aimed at assessing the role of mitochondrial function in tumorigenicity have also yielded mixed results. ${ }^{53}$ Cavalli et al. 54 found diminished tumor formation by mtDNA-depleted $\left(\rho^{\circ}\right)$ glioblastoma and breast and brain tumor cells. Arnould et al. ${ }^{55}$ showed reduced proliferation of osteosarcoma cells following mtDNA depletion. However, Morais et al. ${ }^{56}$ Biswas et al. ${ }^{23}$ and Amuthan et al. ${ }^{25}$ found increased capacity to proliferate and form tumors in vivo and in vitro by cervical carcinoma, osteosarcoma, C2C12 rhabdomyosarcoma, and lung carcinoma cells subjected to mitochondrial stress. It is also known that mtDNA depletion renders some cells more sensitive to apoptotic stimuli, ${ }^{57}$ while opposite effects have been reported in other cells. ${ }^{52}$ In this regard, C2C12 and A549 lung carcinoma cells belong to the latter category since mtDNA depletion makes these cells more resistant to STPmediated apoptosis. It is quite likely that the disparity in the literature on the role of mtDNA depletion on tumorigenic properties of different cells is related to the ability of different cell types to resist apoptosis. ${ }^{53}$ We therefore propose that the observed resistance to apoptosis in $\mathrm{C} 2 \mathrm{C} 12$ rhabdomyoblasts and A549 cells (results not shown) is directly or indirectly related to their increased invasive behavior and tumorigenic property.

\section{Materials and Methods}

\section{Cell lines and treatment}

C2C12 skeletal myoblasts were grown in high glucose DMEM (Life Technology Inc) containing $10 \%$ fetal bovine serum and $0.1 \%$ gentamicin. Depletion of mtDNA was carried out by ethidium bromide treatment $(100 \mathrm{ng} / \mathrm{ml})$ for $\sim 70$ passages as described before. ${ }^{23}$ Clones of cells containing $40-80 \%$ reduced mtDNA contents were selected and grown in presence of $1 \mathrm{mM}$ sodium pyruvate and $50 \mu \mathrm{g} / \mathrm{ml}$ uridine, ${ }^{23}$ and frozen as aliquots in liquid $\mathrm{N}_{2}$. One cell line exhibiting $>80 \%$ reduction in mtDNA content (hereafter referred to as mtDNA-depleted cells) was grown for 50 cycles in the absence of ethidium bromide to generate reverted cells whose mtDNA content was restored to about $90 \%$ of control cell level. To ensure uniform levels of mtDNA, aliquots of the same cell isolates were used in all experiments and the mtDNA levels were assessed before each experiment.

\section{Assay for apoptosis}

Both normal and mtDNA-depleted cells were grown on lysine coated glass coverslips in six-well plates. The cells were treated with $2 \mu \mathrm{M}$ STP for $4 \mathrm{~h}$ to induce apoptosis. The extent of nuclear DNA breaks characteristic of cells undergoing apoptosis was measured by the 
a Anti-DGX
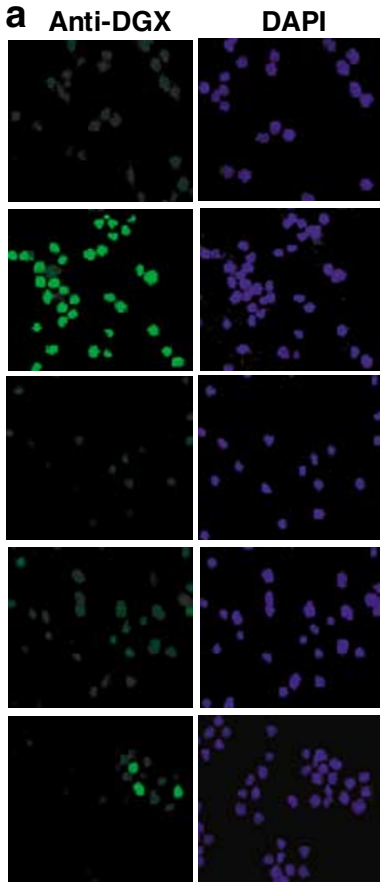

Normal+HA14-1

Normal+HA14-1+STP

Dep+HA14-1
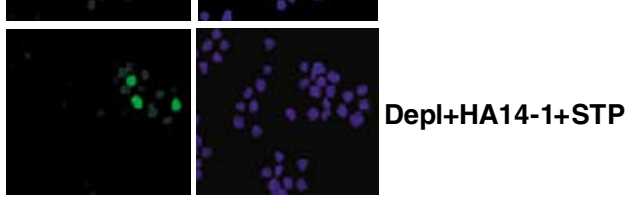

b

b tBid:
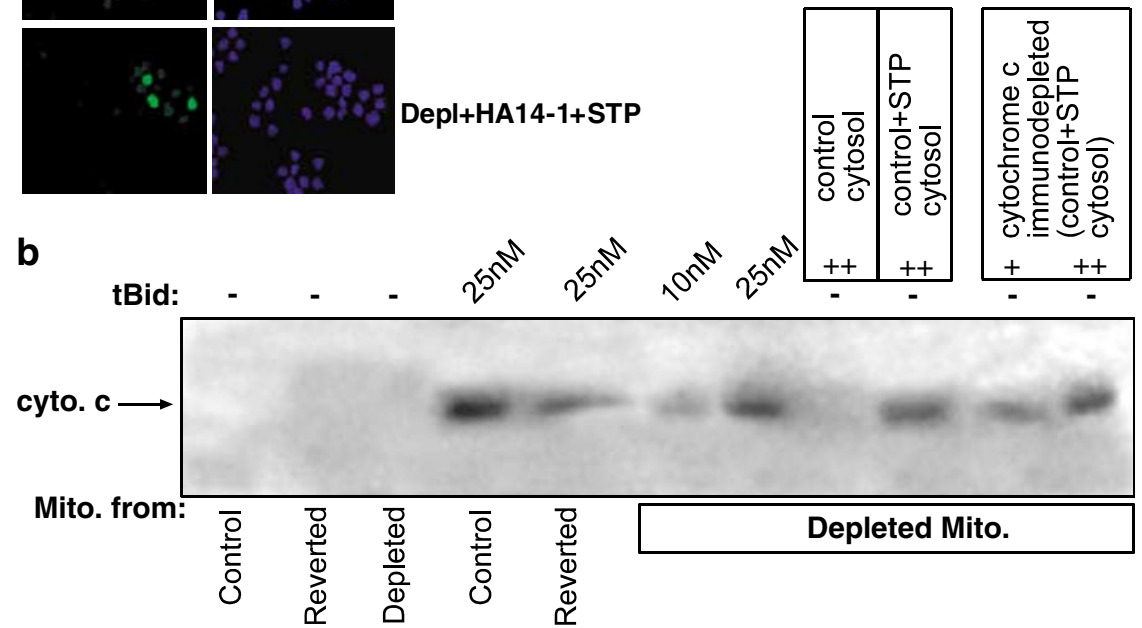

Figure 8 Effects of Bcl2 inhibitor HA14-1 and tBid on apoptosis or cytochrome $c$ release from isolated mitochondria. (a) Control and mtDNA-depleted cells were subjected to TUNEL assay following with or without treatment with STP $(2 \mu \mathrm{M})$ and HA14-1 $(50 \mu \mathrm{M})$ as described in Materials and Methods and Figure 2a. Counterstaining with DAPI was also as described in Figure 2a. (b) Effects of added tBid on cytochrome $c$ release. In vitro reactions with intact isolated mitochondria from control and mtDNA-depleted cells ( $100 \mu \mathrm{g}$ in $30 \mu \mathrm{l}$ reaction volume) were carried out as described in the Materials and Methods section. In some reactions, cytosol from control C2C12 cells, cells treated with STP or cytosol depleted of cyt $c(+=30 \mu \mathrm{g}$, and $++=60 \mu \mathrm{g}$ protein) were added. The post mitochondrial fractions from these incubations were subjected to immunoblot analysis using antibody to cyt $c$ as described in the Materials and Methods section

TUNEL assay where cells were labeled with antidigoxigenin fluorescein (anti-DGX-Fl) using the ApopTag Fluorescein, from the In situ Apoptosis detection kit obtained from Intergen Company, as per the manufacturer's instructions. The coverslips were mounted on slides using mounting medium from the Prolong Antifade kit (Molecular Probes) mixed with 4', 6-Diamidino-2-phenylindole (DAPI) to stain the nucleus. The slides were subjected to fluorescence microscopy at Ex/Em-350/470 for DAPI and Ex/Em-496/518 for FITC using Olympus BX61 fluorescence microscope.

\section{Isolation of mitochondria}

Cells were harvested in mitochondrial isolation buffer (MIB) containing $210 \mathrm{mM}$ mannitol, $60 \mathrm{mM}$ sucrose, $10 \mathrm{mM} \mathrm{KCl}, 10 \mathrm{mM}$ sodium succinate, 5 mM EGTA, 2 mM HEPES-KOH (pH 7.4), 0.5 mM DTT, 1 mM PMSF and COMPLETE protease inhibitor cocktail from Roche Biochemicals. The cells were homogenized in a handheld glass homogenizer ( $\sim 35$ up and down strokes) and mitochondria were isolated by differential centrifugation as described earlier. ${ }^{23,26}$ In order to reduce the level of crosscontamination, mitochondrial suspension in $200 \mu \mathrm{l}$ of MIB was overlaid on a $0.8 \mathrm{M}$ sucrose cushion, and centrifuged at $13500 \times$ r.p.m. for $30 \mathrm{~min}$ at $4^{\circ} \mathrm{C}$. Resulting mitochondrial pellet was assayed for mitochondrial and ER marker enzymes ${ }^{26}$ and was routinely found to contain less than $1 \%$ contamination. Cytosolic fraction was obtained by centrifugation of the postmitochondrial supernatant at $120000 \times g$ for $1 \mathrm{~h}$ in Sorvall $\mathrm{RC}$ M120EX microcentrifuge.

In some experiments, mitochondrial preparations were treated with digitonin (75 $\mu \mathrm{g}$ digitonin/mg mitochondrial protein in $1 \mathrm{ml}$ of MIB) for $2 \mathrm{~min}$ on ice. Digitonin was diluted with $4 \times$ volume of MIB and the resulting mitoplasts, relatively free of outer membrane, were pelleted down by centrifugation at $13000 \times g$ as described above. In some experiments, mitochondrial preparations were treated with trypsin (30 $\mu \mathrm{g}$ trypsin/mg protein in $0.1 \mathrm{ml}$ of MIB) for $20 \mathrm{~min}$ on ice as described before. ${ }^{27}$ The reaction mixture was treated with $10 \mathrm{M}$ excess of trypsin inhibitor, and 


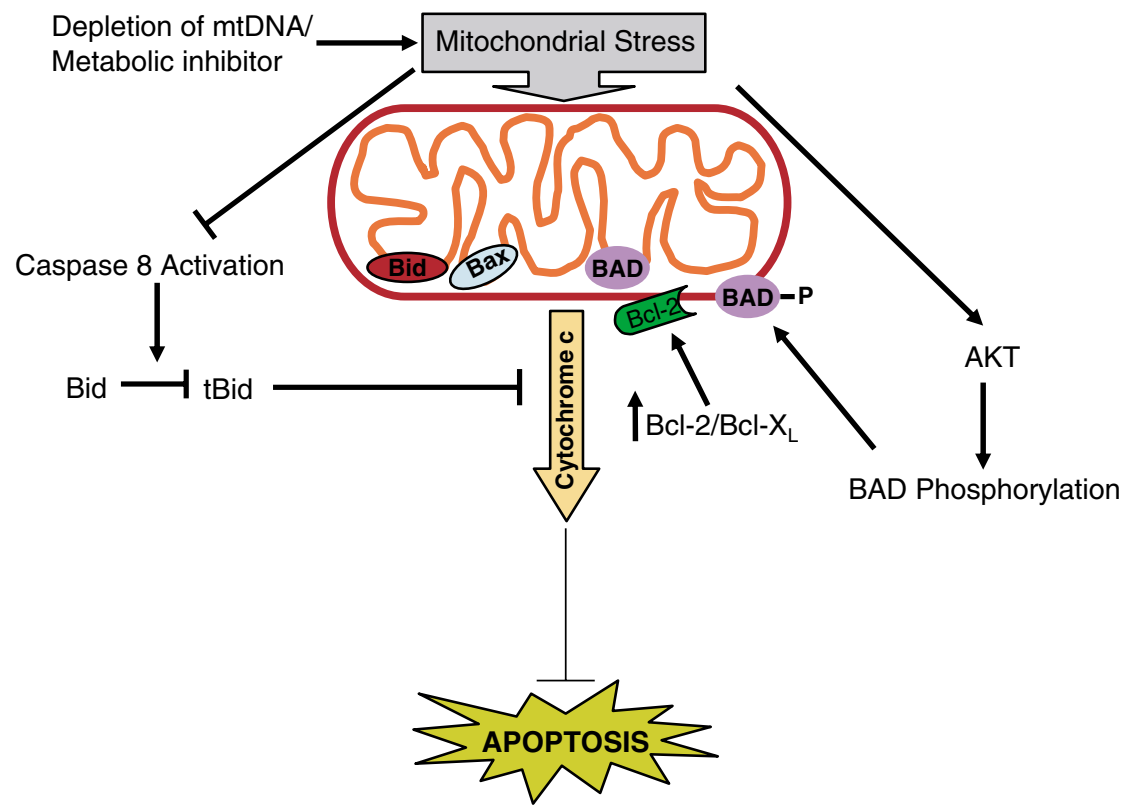

Figure 9 A model for mitochondrial stress-induced resistance to apoptosis in $\mathrm{C} 2 \mathrm{C} 12$ cells. Note that the major part of the mitochondrial BAD, Bax and Bid protein pool is associated with the inner membrane and mostly remains unphosphorylated. A relatively small fraction of $B A D$, which is phosphoryalted and all of $B c l-2 / B c l-X_{L}$ are associated with outer membrane. The model suggests that although $\mathrm{Bcl}-2 / \mathrm{Bcl}-\mathrm{X}_{\mathrm{L}}$ levels are markedly increased during mitochondrial stress, they may not be the primary cause of acquired resistance to apoptosis because of their inability to sequester proapoptotic proteins localized on the inner membrane. Based on the effects of added tBid in the in vitro system, the model suggests that inability to process Bid is a major reason for acquired resistance to apoptosis in mtDNA-depleted cells

mitochondria were recovered by sedimentation through $0.8 \mathrm{M}$ sucrose as described above.

\section{Immunoblot analysis}

The protein content was estimated by Lowry's method. ${ }^{28}$ Cytosolic or mitochondrial proteins (30 $\mu \mathrm{g})$ solubilized in Laemmli's sample buffer were resolved by electrophoresis on $10 \%$ Tricine gels and subjected to immunoblot analysis using respective antibodies. The types and sources of antibodies used were: monoclonal antibodies against human COX I from Molecular Probes Inc. (OR, USA) and polyclonal antibodies against human adrenodoxin (Adx) were generated in house. ${ }^{27}$ Polyclonal antibodies against cyt $c$, Smac, Actin, Bax, BAD, Bid, Bcl-X, Bcl-2, Survivin, caspases 3, 8, and 9, and AKT were from Santa Cruz Biotech. The immunoblots were developed using Pierce super signal reagent as described before. ${ }^{23}$

\section{Mitochondrial membrane potential $\left(\Delta \Psi_{\mathrm{m}}\right)$}

The $\Delta \Psi_{\mathrm{m}}$ was assayed spectrofluorometrically by loading the cells with a cationic dye, Mito Tracker Orange (MTO) $\mathrm{CM}-\mathrm{H}_{2}$ TMRos (Molecular Probe Inc.) The reduced form of the dye is taken up by mitochondria in proportion to $\Delta \Psi_{\mathrm{m}}$, which fluoresces upon oxidation inside respiring mitochondria. The $\Delta \Psi_{\mathrm{m}}$ was measured using a procedure described before. ${ }^{25}$ Cells were loaded with the dye using a procedure modified from Szalai et al. ${ }^{29}$ Briefly, control and STP-treated cells were trypsinized and washed once with serum-free medium and pelleted down at low speed. The cell pellet was suspended and washed in extra cellular buffer (ECM) containing $120 \mathrm{mM} \mathrm{NaCl}, 5 \mathrm{mM} \mathrm{KCl}, 1 \mathrm{mM} \mathrm{KH}_{2} \mathrm{PO}_{4}, 0.2 \mathrm{mM} \mathrm{MgCl}_{2}, 0.1 \mathrm{mM}$ EGTA, $20 \mathrm{mM}$ HEPES-Tris, $\mathrm{pH}$ 7.2. Each assay was carried out with $\sim 8 \times 10^{6}$ cells suspended in $1 \mathrm{ml}$ of ECM. MTO CM-H $\mathrm{TMRos}_{2}\left(50 \mathrm{nM} / 6 \times 10^{6}\right)$ was added directly to $1 \mathrm{ml}$ cell suspension in the cuvette. The rate of uptake of the dye was recorded as a measure of $\Delta \Psi_{\mathrm{m}}$ using a Delta RAM PTI spectrofluorometer. The dye was excited at $525 \mathrm{~nm}$ and fluorescence was detected at $575 \mathrm{~nm}$. The data were recorded as fluorescence units per minute as described before. ${ }^{25}$

\section{Immunocytochemistry}

To assess the time course of cyt $c$ release, control and mtDNA-depleted cells were grown on coverslips and treated with $2 \mu \mathrm{M} \mathrm{STP} \mathrm{(Sigma} \mathrm{Co.)} \mathrm{for}$ different time periods. Cells were immunostained with cyt $c$ antibody as described before. ${ }^{23}$ Briefly, cells were fixed with $2 \%$ paraformaldehyde (30 $\mathrm{min})$, permeabilized with $0.1 \%$ Triton X-100 (10 min) and blocked with $5 \%$ goat serum for $1 \mathrm{~h}$ at $37^{\circ} \mathrm{C}$. Cells were immunostained with $1: 100$ dilution of cyt $c$ antibody (Santa Cruz Biotech. Inc.) for $1 \mathrm{~h}$ at $37^{\circ} \mathrm{C}$. Cells were rinsed with phosphate-buffered saline (PBS) to remove unbound antibody and incubated with $1: 100$ dilutions of fluorescein isothiocyanate (FITC)-conjugated anti-mouse antibody (Jackson ImmunoResearch laboratories, Inc., West Grove, PA, USA), for $1 \mathrm{~h}$ at $37^{\circ} \mathrm{C}$. Unbound secondary antibodies were removed by repeated washing with PBS. Fluorescence microscopy was carried out under a TCS laser scanning microscope (Leica Inc., Deerfield, IL, USA). Optical sections of $0.5 \mu \mathrm{m}$ were scanned at the $z$-axis.

\section{Immunoprecipitation of BAD}

Immunoprecipitaion of BAD from mitochondria and cytosol was carried out using $500 \mu \mathrm{g}$ of cytosolic or mitochondrial proteins. Mitochondrial proteins were solubilized in a buffer containing $10 \mathrm{mM}$ Tris- $\mathrm{Cl}, \mathrm{pH} 7.4,10 \%$ glycerol, $0.5 \mathrm{mM}$ EDTA, $0.1 \%$ NP40 and $0.1 \%$ Triton X-100 and protease inhibitors on a rotating shaker overnight at $4^{\circ} \mathrm{C}$. The soluble fraction was 
recovered by centrifugation at $100000 \times g$ for $45 \mathrm{~min}$ in Sorvall $\mathrm{RC}$ M120EX microcentrifuge. Cytosolic fraction was isolated as described before. ${ }^{23}$ Immunoprecipitation of mitochondrial and cytosolic proteins with BAD antibody (Santa Cruz Biotech. Inc.) was carried out using the protein A-agarose pull-down method as previously described. ${ }^{30}$ The immunoprecipitates were extracted from the beads with $2 \times$ Laemmli buffer devoid of $\beta$-mercaptoethanol at $95^{\circ} \mathrm{C}$ for $5 \mathrm{~min}$. The samples were analyzed by Western blot analysis using antibody to phospho-Ser (SigmaAldrich).

\section{Immunodepletion of cytochrome $c$ from the cytosolic fraction}

Anti-cyt $c$ antibody (6H2. B4, from Pharmingen), which recognizes the native form of cyt $c$ was used to deplete cyt $c$ from the cytosolic fractions of STP treated and untreated cells as described by Liu et al. ${ }^{31}$ An amount of $50 \mu \mathrm{l}$ of the antibody was incubated with $50 \mu \mathrm{l}$ slurry of protein Aconjugated agarose in a final volume of $200 \mu \mathrm{l}$ in $1 \times$ PBS containing protease inhibitors. The incubation was carried out at $4^{\circ} \mathrm{C}$ for $4 \mathrm{~h}$. The agarose beads were collected by centrifugation, supernatant was removed and the pellet was washed twice with $1 \times$ PBS containing the protease inhibitors. The pellet was incubated with $1 \mathrm{ml}$ of cytosolic protein (5 mg protein) from STP-treated control cells for $4 \mathrm{~h}$ at $4^{\circ} \mathrm{C}$ on a tilt shaker. The immunodepleted supernatant was recovered by centrifugation at $100000 \times g$ in a microultracentrifuge for $10 \mathrm{~min}$, and the supernatant was checked for cyt $c$ content by immunoblot analysis. Cytosolic fraction free of detectable cyt $c$ was stored at $-80^{\circ} \mathrm{C}$ until use.

\section{Assay of cytochrome $c$ release by isolated mitochondria in response to tBid addition}

cyt $c$ release in response to added tBid was assayed in vitro using isolated mitochondria and cytosolic fractions essentially as described by Wei et al. ${ }^{32}$ and Luo et al. ${ }^{33}$ Briefly, reaction was carried out with $100 \mu \mathrm{g}$ mitochondrial protein in $30 \mu \mathrm{l}$ of assay mixture containing $250 \mathrm{mM}$ sucrose, $10 \mathrm{mM}$ HEPES, $1 \mathrm{mM}$ ATP, $5 \mathrm{mM}$ succinate, $80 \mu \mathrm{M}$ ADP, $2 \mathrm{mM} \mathrm{K}_{2} \mathrm{HPO}_{4}(\mathrm{pH} 7.4)$, $2 \mathrm{mM} \mathrm{Mg}\left(\mathrm{C}_{2} \mathrm{H}_{3} \mathrm{O}_{2}\right)_{2}, 80 \mathrm{mM} \mathrm{KCl}$. Purified recombinant tBid (10 or $25 \mathrm{nM}$, Sigma-Aldrich) was added to the tubes and the reaction was carried out at $30^{\circ} \mathrm{C}$ for $30 \mathrm{~min}$. In some reactions, the mitochondrial suspensions were incubated with 30 or $60 \mu \mathrm{g}$ of cytosolic protein from STP treated, cyt $c$ immunodepleted, or untreated control cells. At the end of reaction, the mitochondria were pelleted down at $12000 \times g$ for $5 \mathrm{~min}$ at $4^{\circ} \mathrm{C}$, washed with MIB and the supernatant was mixed with $5 \mu \mathrm{l}$ of $6 \times$ Laemmli's sample buffer. The mitochondrial pellet was suspended in $30 \mu \mathrm{l}$ of $1 \times$ Laemmli's sample buffer. The proteins were resolved on a $14 \%$ SDSPAGE and analyzed by Western blot using cyt $c$ antibody.

\section{Acknowledgements}

We are thankful to the members of Avadhani laboratory for useful suggestions and criticisms and to Dr. Michael May for a generous gift of caspase 8 antibody. This research was supported by $\mathrm{NIH}$ Grant CA22762-26

\section{References}

1. Eskes R, Antonsson B, Osen-Sand A, Montessuit S, Richter C, Sadoul R, Mazzei G, Nichols A and Martinou JC (1998) Bax-induced cytochrome $c$ release from mitochondria is independent of the permeability transition pore but highly dependent on $\mathrm{Mg}^{2+}$ ions. J. Cell Biol. 143: 217-224

2. Rosse T, Olivier R, Monney L, Rager M, Conus S, Fellay I, Jansen B and Borner C (1998) Bcl-2 prolongs cell survival after Bax-induced release of cytochrome $c$. Nature 39: 496-499

3. Kluck RM, Bossy-Wetzel E, Green DR and Newmeyer DD (1997) The release of cytochrome $c$ from mitochondria: a primary site for Bcl-2 regulation of apoptosis. Science 275: 1132-1136

4. Jurgensmeier JM, Xie Z, Deveraux Q, Ellerby L, Bredesen D and Reed JC (1998) Bax directly induces release of cytochrome $C$ from isolated mitochondria. Proc. Natl. Acad. Sci. USA 95: 4997-5002

5. Wang X (2001) The expanding role of mitochondria in apoptosis. Genes Dev. 15: 2922-2933

6. Rutter GA and Rizzuto R (2000) Regulation of mitochondrial metabolism by ER $\mathrm{Ca}^{2+}$ release: an intimate connection. Trends Biochem. Sci. 25: 215-221

7. Hengartner MO (2000) The biochemistry of apoptosis. Nature 407: 770-776

8. Green DR and Reed JC (1998) Mitochondria and apoptosis. Science 281: 1309-1311

9. Kroemer G, Dallaporta B and Resche-Rigion M (1998) The mitochondrial death/life regulator in apoptosis and necrosis. Annu. Rev. Physiol. 60: 619-642

10. Reed JC (1997) Cytochrome c: Can't live with it-Can't live without it. Cell 91: $559-562$

11. Verhagen AM, Ekert PG, Pakusch M, Silke J, Connolly LM, Reid GE, Moritz RL, Simpson RJ and Vaux DL (2000) Identification of DIABLO, a mammalian protein that promotes apoptosis by binding to and antagonizing IAP proteins. Cell 102: 43-53

12. Lindenboim L, Borner $\mathrm{C}$ and Stein $\mathrm{R}$ (2001) Bcl-x(S) can form homodimers and heterodimers and its apoptotic activity requires localization of $\mathrm{Bcl}-\mathrm{x}(\mathrm{S})$ to the mitochondria and its BH3 and loop domains. Cell Death Differ. 8: 933-942

13. Chao DT and Korsmeyer SJ (1998) BCL-2 family: regulators of cell death. Annu. Rev. Immunol. 16: 395-419

14. Borner C (2003) The Bcl-2 protein family: sensors and checkpoints for life-ordeath decisions. Mol. Immunol. 39: 615-647

15. Wang HG, Miyashita T, Takayama S, Sato T, Torigoe T, Krajewski S, Tanaka S, Hovey III L, Troppmair J and Rapp UR (1994) Apoptosis regulation by interaction of Bcl-2 protein and Raf-1 kinase. Oncogene 9: 2751-2756

16. Wang HG, Rapp UR and Reed JC (1996) Bcl-2 targets the protein kinase Raf-1 to mitochondria. Cell 87: 629-638

17. Neshat MS, Raitano AB, Wang HG, Reed JC and Sawyers CL (2000) The survival function of the Bcr-Abl oncogene is mediated by Bad-dependent and independent pathways: roles for phosphatidylinositol 3-kinase and Raf. Mol. Cell. Biol. 20: 1179-1186

18. Mignotte B and Vayssiere $\mathrm{JL}$ (1998) Mitochondria and apoptosis. Eur. J. Biochem. 252: 1-15

19. Kroemer G, Zamzami N and Susin SA (1997) Mitochondrial control of apoptosis. Immunol. Today 18: 44-51

20. Bossy-Wetzel E, Newmeyer DD and Green DR (1998) Mitochondrial cytochrome $c$ release in apoptosis occurs upstream of DEVD-specific caspase activation and independently of mitochondrial transmembrane depolarization. EMBO J. 17: 37-49

21. Joshi B, Li L, Taffe BG, Zhu Z, Wahl S, Tian H, Ben-Josef E, Taylor JD, Porter AT and Tang DG (1999) Apoptosis induction by a novel anti-prostate cancer compound, BMD188 (a fatty acid-containing hydroxamic acid), requires the mitochondrial respiratory chain. Cancer Res. 59: 4343-4355

22. Finucane DM, Waterhouse NJ, Amarante-Mendes GP, Cotter TG and Green DR. (1999) Collapse of the inner mitochondrial transmembrane potential is not required for apoptosis of HL60 cells. Exp. Cell Res. 251: 166-174

23. Biswas $G$, Adebanjo $O A$, Freedman BD, Anandatheerthavarada HK, Vijayasarathy C, Zaidi M, Kotlikoff M and Avadhani NG (1999) Retrograde $\mathrm{Ca}^{2+}$ signaling in $\mathrm{C} 2 \mathrm{C} 12$ skeletal myocytes in response to mitochondrial genetic and metabolic stress: a novel mode of inter-organelle crosstalk. EMBO J. 18: 522-533

24. Amuthan G, Biswas G, Zhang SY, Klein-Szanto A, Vijayasarathy C and Avadhani NG (2001) Mitochondria-to-nucleus stress signaling induces phenotypic changes, tumor progression and cell invasion. EMBO J. 20: 1910-1920

25. Amuthan G, Biswas G, Ananadatheerthavarada HK, Vijayasarathy C, Shephard HM and Avadhani NG (2002) Mitochondrial stress-induced 
calcium signaling, phenotypic changes and invasive behavior in human lung carcinoma A549 cells. Oncogene 21: 7839-7849

26. Addya S, Anandatheerthavarada HK, Biswas G, Bhagwat SV, Mullick J and Avadhani NG (1997) Targeting of NH2-terminal-processed microsomal protein to mitochondria: a novel pathway for the biogenesis of hepatic mitochondrial P450MT2. J. Cell Biol. 139: 589-599

27. Anandatheerthavarada HK, Addya S, Dwivedi RS, Biswas G, Mullick J and Avadhani NG. (1997) Localization of multiple forms of inducible cytochromes P450 in rat liver mitochondria: immunological characteristics and patterns of xenobiotic substrate metabolism. Arch. Biochem. Biophys. 339: $136-150$

28. Lowry $\mathrm{OH}$, Rosebrough NJ, Farr $\mathrm{AL}$ and Randall RJ (1951) Protein measurement with the Folin Phenol reagent. J. Biol. Chem. 193: 265-275

29. Szalai G, Krishnamurthy R. and Hajnóczky G (1999) Apoptosis driven by $\mathbb{I P}_{3^{-}}$linked mitochondrial calcium signals. EMBO J. 18: 6349-6361

30. Anandatheerthavarada HK, Biswas G, Mullick J, Sepuri NB, Otvos L, Pain D and Avadhani NG (1999) Dual targeting of cytochrome P4502B1 to endoplasmic reticulum and mitochondria involves a novel signal activation by cyclic AMP-dependent phosphorylation at ser128. EMBO J. 18: 5494-5504

31. Liu X, Kim CN, Yang J, Jemmerson R and Wang X (1996) Induction of apoptotic program in cell-free extracts: requirement for dATP and cytochrome c. Cell 86: 147-157

32. Wei MC, Lindsten T, Mootha VK, Weiler S, Gross A, Ashiya M, Thompson CB and Korsmeyer SJ (2000) tBID, a membrane-targeted death ligand, oligomerizes BAK to release cytochrome c. Genes Dev. 14: 20602071

33. Luo X, Budihardjo I, Zou H, Slaughter C and Wang X (1998) Bid, a Bcl2 interacting protein, mediates cytochrome $c$ release from mitochondria in response to activation of cell surface death receptors. Cell 94: 481-490

34. Khaled AR, Reynolds DA, Young HA, Thompson CB, Muegge $\mathrm{K}$ and Durum SK (2001) Interleukin-3 withdrawal induces an early increase in mitochondrial membrane potential unrelated to the Bcl-2 family. Roles of intracellular $\mathrm{pH}, \mathrm{ADP}$ transport, and $\mathrm{F}(0) \mathrm{F}(1)$-ATPase. J. Biol. Chem. 276: 6453-6462

35. Vander Heiden MG, Chandel NS, Schumacker PT and Thompson CB (1999) $\mathrm{Bcl}-\mathrm{xL}$ prevents cell death following growth factor withdrawal by facilitating mitochondrial ATP/ADP exchange. Mol. Cell. 3: 159-167

36. Banki K, Hutter E, Gonchoroff NJ and Perl A (1999) Elevation of mitochondrial transmembrane potential and reactive oxygen intermediate levels are early events and occur independently from activation of caspases in Fas signaling. J. Immunol. 162: 1466-1479

37. Wang JL, Liu D, Zhang ZJ, Shan S, Han X, Srinivasula SM, Croce CM, Alnemri ES and Huang Z (2000) Structure-based discovery of an organic compound that binds Bcl-2 protein and induces apoptosis of tumor cells. Proc. Natl. Acad. Sci. USA 97: 7124-7129

38. Desagher S, Osen-Sand A, Nichols A, Eskes R, Montessuit S, Lauper S, Maundrell K, Antonsson B and Martinou JC (1999) Bid-induced conformationa change of $\mathrm{Bax}$ is responsible for mitochondrial cytochrome $c$ release during apoptosis. J. Cell Biol. 144: 891-901

39. Eskes R, Desagher S, Antonsson B and Martinou JC (2000) Bid induces the oligomerization and insertion of Bax into the outer mitochondrial membrane. Mol. Cell. Biol. 20: 929-935

40. Korsmeyer SJ, Wei MC, Saito M, Weiler S, Oh KJ and Schlesinger PH (2000) Pro-apoptotic cascade activates BID, which oligomerizes BAK or
BAX into pores that result in the release of cytochrome c. Cell Death Differ. 7: 1166-1173

41. Narita M, Shimizu S, Ito T, Chittenden T, Lutz RJ, Matsuda $H$ and Tsujimoto $Y$ (1998) Bax interacts with the permeability transition pore to induce permeability transition and cytochrome $c$ release in isolated mitochondria. Proc. Natl. Acad. Sci. USA 95: 14681-14686

42. Shimizu S, Narita M and Tsujimoto $Y$ (1999) Bcl-2 family proteins regulate the release of apoptogenic cytochrome $c$ by the mitochondrial channel VDAC. Nature 399: 483-487

43. Marzo I, Brenner C, Zamzami N, Jurgensmeier JM, Susin SA, Vieira HL, Prevost MC, Xie Z, Matsuyama S, Reed JC and Kroemer G (1998) Bax and adenine nucleotide translocator cooperate in the mitochondrial control of apoptosis. Science 281: 2027-2031

44. Goldstein JC, Waterhouse NJ, Juin P, Evan Gl and Greed DR (2000) The coordinate release of cytochrome $c$ during apoptosis is rapid, complete and kinetically invariant. Nat. Cell Biol. 2: 156-162

45. Kelekar A and Thompson CB (1998) Bcl-2-family proteins: the role of the $\mathrm{BH} 3$ domain in apoptosis. Trends Cell Biol. 8: 324-330

46. Adachi M and Imai K (2002) The proapoptotic BH3-only protein BAD transduces cell death signals independently of its interaction with Bcl-2. Cell Death Differ. 9: 1240-1247

47. Marsden VS and Strasser A (2003) Control of apoptosis in the immune system: $\mathrm{Bcl}-2$, BH3-only proteins and more. Annu. Rev. Immunol. 21: 71-105

48. Zha J, Weiler S, Oh KJ, Wei MC and Korsmeyer SJ (2000) Posttranslational Nmyristoylation of BID as a molecular switch for targeting mitochondria and apoptosis. Cell 290: 1761-1765

49. Yang E, Zha J, Jockel J, Boise LH, Thompson CB and Korsmeyer SJ (1995) $\mathrm{BAD}$, a heterodimeric partner for bcl-xl and bcl-2, displaces bax and promotes cell death. Cell 80: 285-291

50. Zha J, Harada H, Yang E, Jockel J and Korsmeyer SJ (1996) Serine phosphorylation of death agonist BAD in response to survival factors results in binding to 14-3-3 not BCL-XL. Cell 87: 619-628

51. Virdee K, Parone PA and Tolkovsky AM (2000) Phosphorylation of the proapoptotic protein BAD on serine 155, a novel site, contributes to cell survival. Curr. Biol. 10: 1151-1154

52. Dey R and Moraes CT (2000) Lack of oxidative phosphorylation and low mitochondrial membrane potential decrease susceptibility to apoptosis and do not modulate the protective effect of $\mathrm{Bcl}-\mathrm{x}(\mathrm{L})$ in osteosarcoma cells. J. Biol. Chem. 275: 7087-7094

53. Butow R and Avadhani NG (2004) Mitochondrial signaling: the retrograde response. Mol. Cell. 14: 1-15

54. Cavalli LR, Varella-Garcia M and Liang BC (1997) Diminished tumorigenic phenotype after depletion of mitochondrial DNA. Cell Growth Differ. 8: $1189-1198$

55. Arnould T, Vankoningsloo S, Renard P, Houbion A, Ninane N, Demazy C, Remacle $\mathrm{J}$ and Raes M (2002) CREB activation induced by mitochondrial dysfunction is a new signaling pathway that impairs cell proliferation. EMBO J. 21: $53-63$

56. Morais R, Zinkewich-Peotti K, Parent M, Wang H, Babai F and Zollinger M (1994) Tumor-forming ability in athymic nude mice of human cell lines devoid of mitochondrial DNA. Cancer Res. 54: 3889-3896

57. Jiang S, Cai J, Wallace DC and Jones DP (1999) Cytochrome c-mediated apoptosis in cells lacking mitochondrial DNA. Signaling pathway involving release and caspase 3 activation is conserved. J. Biol. Chem. 274: 29905-29911 